\title{
Influence of Financial Performance and Capital Structure on Company Growth and Company Value of Advertising, Printing and Media Companies in Indonesian Stock Exchange
}

\author{
Husnul Muamilah \\ Magister Candidate, Graduate School of Economics \\ Hasanuddin University, Makassar \\ South Sulawesi, Indonesia \\ Muhammad Asdar \\ Professor of Economics, Graduate School of Economics \\ Hasanuddin University, Makassar \\ South Sulawesi, Indonesia \\ Muhammad Sobarsyah \\ Ph.D of Economics, Graduate School of Economics \\ Hasanuddin University, Makassar \\ South Sulawesi, Indonesia
}

DOI: $10.31364 / \mathrm{SCIRJ} / \mathrm{v} 7 . \mathrm{i} 1.2019 . \mathrm{P} 0119600$

http://dx.doi.org/10.31364/SCIRJ/v7.i1.2019.P0119600

\begin{abstract}
This research aims to examine and to analyze the influence of financial performance and capital structure on company growth and company value in advertising, printing and media companies listed in Indonesian Stock Exchange (IDX) in period from 2013 until 2017.
\end{abstract}

Populations of 15 companies were selected with purposive sampling to select nine companies that met the sample criteria. The data obtained through Indonesian Stock Exchange (IDX) and the websites of companies. Data were analyzed using panel data regression with Eviews 10.

The results show that (1) financial performance affects company growth positively and significantly, (2) capital structure affects company growth positively and significantly, (3) financial performance affects company value positively and significantly, (4) capital structure affects company value positively and significantly (5) company growth affects company value negatively and significantly.

Keywords: financial performance, capital structure, company growth and company value.

\section{INTRODUCTION}

The development of globalization and free trade requires every company to be able to compete. When the ASEAN Economic Community (MEA) agreement was carried out in 2016, it contained a number of concerns. Starting from concerns, Indonesia is only used as a market for external products and unpreparedness of Indonesian human resources in competing with neighboring countries. However, this can be refused by looking at Indonesia's per capita income which is assessed from its purchasing power parity. Based on data from the International Monetary Fund (IMF) year of 2017, Indonesia is in 5th position with US\$13,120, this means that the level of community's economy is increasing compared to other countries in ASEAN. The strengthened Indonesian economy is characterized by Indonesia's per capita income which continues to increase, making the growth of advertising, printing and national media industry. 
The advertising, printing and Indonesian media industry is one of the industries that has a large potential market share and growth especially entering the digital era of 4.0 making the industry moves quickly to be able to control it. This is according to data from the Statistics Indonesia (BPS) that the digital share shows increased contribution from 2016 of $3.61 \%$ increased by 4\% in 2017 toward Indonesia's gross domestic product (GDP). By seeing the huge growth potential, it is not impossible that this industry is able to take advantage of the current digital era.

The advertising, printing and Indonesian media industry is an industry that has a large potential of market share and growth, certainly investors expect an increase in the value of the company which is one of the financial management efforts, so that investors can invest even bigger by looking at the value of companies and potential investors interested in the industry that is reflected in the company's share price.

Table 1.

Share Price of Advertising, Printing and Media Companies

\begin{tabular}{|c|r|r|r|r|r|}
\hline SHARE CODE & $\mathbf{2 0 1 3}$ & $\mathbf{2 0 1 4}$ & $\mathbf{2 0 1 5}$ & $\mathbf{2 0 1 6}$ & $\mathbf{2 0 1 7}$ \\
\hline ABBA & 100 & 61 & 50 & 50 & 50 \\
\hline EMTK & 5550 & 7800 & 10300 & 9975 & 9500 \\
\hline FORU & 167 & 700 & 700 & 318 & 125 \\
\hline JTPE & 305 & 378 & 232 & 308 & 274 \\
\hline KBLV & 580 & 2590 & 1875 & 1215 & 428 \\
\hline MNCN & 2625 & 2540 & 1855 & 1755 & 1285 \\
\hline MSKY & 2000 & 1600 & 1335 & 1045 & 780 \\
\hline SCMA & 2625 & 3500 & 3100 & 2800 & 2480 \\
\hline TMPO & 158 & 116 & 66 & 143 & 268 \\
\hline
\end{tabular}

Source: Annual report of Advertising, Printing and Media Companies year of 2013-2017

Based on table 1. indirectly the share price in advertising, printing and media companies affects the value of the company, because the value of the company is seen from the prosperity of shareholders as measured by the price of the share. From 2013 to 2017 showed fluctuations from 9 companies that tended to decline, this indicates that investors will assess the company is not good enough at managing resources to achieve company's goals, thus investors' trustworthiness in the company is reduced even though this indicator becomes an important part for prospective investors and the market in looking at the value of the company and if added, then happens the high growth of the company it should increase investors' trustworthiness that the company has good prospects in the future seen from the value of the company.

Besides from the interesting phenomenon of company value, another phenomenon that has occurred in the advertising, printing and media industry is that there have been high sales during the last five years, namely 2013-2017, but not followed by high profits. This is based on data of sales and net income of the advertising, printing and media companies listed on IDX period of 2013-2017 which fluctuated but tended to increase, five out of nine companies experienced increased sales but four of the nine companies were Earning after Tax (EAT) decreased even five other companies experienced negative profits from $2013-2017$. Whereas according to the signaling theory that the actions implemented by management are to explain the financial condition of the company which generally has better information about the prospects of the company in this era and in the future to shareholders (Suteja, 2013). The existence of information or signals whether positive or negative will certainly affect the growth of the company and will have an impact on share prices which will ultimately affect the value of the company.

In order to be able to survive in the industry, companies need to pay attention to the growth rate of the company both in high or low conditions because it will affect the usage of asset elements in the future, therefore special attention is needed to the optimal capital structure for asset usage. According to the pecking order theory that managers, in financing business operations must consider the order in choosing the source of funds (Myers and Majluf. 1984).

This industry is a dynamic industry, with sustainable and diverse growth. However, growth in this industry is not felt thoroughly by businessmen of Advertising, Printing and Media, then is only felt in some industries. Whereas the average growth www.scirj.org 
of this industry is strong with a large market share, thus optimization of its resources is needed in this industry in order to continue to grow and survive. Advertising, printing and media companies make every effort to keep up with the results that they will get. This means that spending on investment in companies can provide a positive signal about the company's growth in the future, so that it will have an impact on increasing share prices as an indicator in the value of the company (Hasnawati, 2005).

The bankrupt trend that has occurred over the past 5 years in this industry such as Sinar Harapan Newspaper, The Jakarta Globe, Bola Magazine, Kompas Gramedia Group and those who decide to close will be experienced by other media companies. Prospective investors will hesitate to invest in this sector. Nevertheless, there is hope from the central government that this sector will continue to grow by incorporating this sector into part of the creative industry sub-sector and becoming part of the main work of the ministry of tourism and no longer being shaded by the ministry of trade which is expected to develop and create new market opportunities for the advertising, printing and media industry maximally.

Based on the description that has been explained, this study aims to ascertain the effect of financial performance and capital structure on the growth of the company and the value of the company with the growth of the company as an intervening variable in the advertising, printing and media companies listed on the IDX.

\section{LITERATURE REVIEW}

\section{Pecking Order Theory}

Pecking order theory according to Myers and Majluf (1984) that managers, in financing business operations must consider the order in choosing the source of funds. This theory concludes that company managers prefer the use of internal funds compared to funds from external parties. This is because there is a lower risk and then funding with a large cost if needed (Colombage, 2007).

\section{Signaling Theory}

Signaling Theory explains that it is best to signal the failure or success of a management that has an impact on the owner (principal). The actions implemented by management are to explain the financial condition of the company which generally has better information about the prospects of the company now and in the future to shareholders (Suteja, 2013).

\section{Capital Structure}

Fabozzi and Peterson (2000), capital structure is the combination of debt and equity used to finance a firm's projects. The capital structure of a firm is some mix of debt, internally generated equity, and new equity. This study uses a debt to asset ratio (DAR) to determine the company's capital structure. DAR is a comparison between total debt and total assets (Kasmir, 2013). The higher this ratio means the greater the amount of loan capital used for investment in assets to generate profits for the company.

\section{Value of The Company}

The market value of the company is the same as the value of the company which is the price that a potential buyer can pay if the company is sold. Company value can be seen through the market value or the book value of the company from the equity it has (Husnan, 2013). The ratio indicator used to measure company value in this study is Price Book to Value (PBV).

\section{Growth of The Company}

The growth of the company illustrates the benchmark of the success of the company and how it is able to place the company in an economic system as a whole or in the same industry (Machfoedz, 1996). The growth of the company can be assessed by increasing profits, increasing equity, increasing sales, and increasing assets (Chen et.al, 2005). Firm growth is measured in this study with profit growth.

\section{Financial Performance}

A company with good financial performance will reflect the condition of the company in good condition as well. The results of financial performance can be used as an evaluation for the company in the future and can also be used as a basis for 
decision making for investors and shareholders (Sawir, 2005). In this study in measuring financial performance using profitability ratios, namely ROA (Return On Asset). The higher the level of profitability (ROA) of a company, the greater the level of prosperity provided by the company will attract investors to own the company and will have a positive impact on stock prices in the market (Safitri and Wahyuati, 2015)

\section{MATERIALS AND METHODS}

\section{Location and Design of Research}

This research was conducted at the advertising, printing and media companies which listed on the Indonesia Stock Exchange (IDX). This type of research was a causality study, which was a causal relationship. This research method was classified as quantitative research. Data analysis techniques used panel data regression analysis by using Eviews 10 .

\section{Population, Sample and Sampling Techniques}

The population in this research were all the advertising, printing and media companies listed on the Indonesia Stock Exchange (IDX) during the period of 2013-2017, which were 15 companies with the number of samples were in accordance with the sampling criteria of 9 companies. The sampling technique used a purposive sampling method with consideration of the advertising, printing and media companies that had been listed on the IDX before 2013 and were still registered until 2017, the company published complete annual report of 2013-2017 and the company had never been delisted on the IDX.

\section{Data Collection Method}

The method of data collection in this research was the method of documentation. The documentation method was carried out by retrieving documents in the form of Indonesian economic data, growth and development of the Advertising, Printing and Media industry, financial performance of the company and quantitative data in the form of financial statements for each service company in the sectors of Advertising, Printing and Media listed on the Indonesia Stock Exchange (IDX) and other supporting data from several publications related to or connected to this research which could be assessed as providing objective information through the website network.

\section{Research Variable}

The research variables were grouped into three groups, namely the dependent variable consisted of company's growth (Y1) measured by Earning Growth (EG) and company's value (Y2) used Price Book Value (PBV), the independent variable consisted of financial performance (X1) was measured by using Return on Assets (ROA), the capital structure (X2) was proxied by Debt to Assets Ratio (DAR), and the intervening variable as the intermediary variable in this research was the growth of the company (Y1).

\section{Data Analysis Technique}

The data analysis technique used to discuss the problem in this research was panel data regression analysis with the help of the Eviews 10 Statistical data processing program. There were three analytical techniques that could be used, namely the Common Effect Method or OLS, the Fixed Effect Method, and the Random Effect Method (Gujarati and Porter, 2013).

\section{Analysis Model}

The equation in this research was as follows:

$\mathrm{Y}_{1 \mathrm{it}}=\mathrm{f}(\mathrm{X} 1, \mathrm{X} 2)$

$\mathrm{Y}_{2 \mathrm{it}} \quad=\mathrm{f}(\mathrm{X} 1, \mathrm{X} 2, \mathrm{Y} 1)$ 


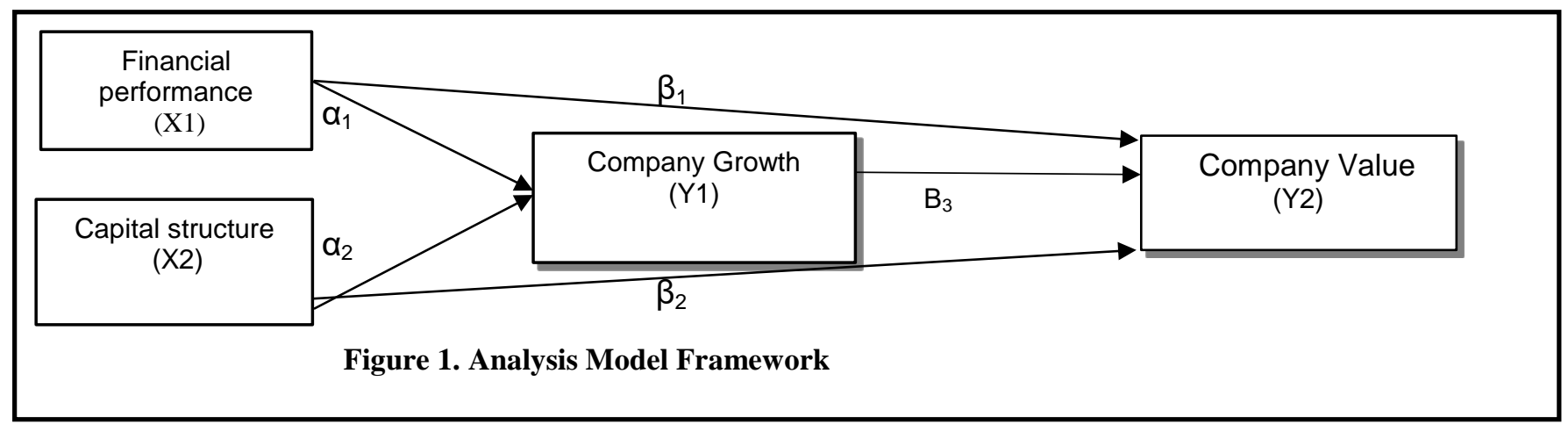

Explanation:

$\alpha_{1}$ : Effect of exogenous variables $\left(\mathrm{X}_{1}\right)$ on endogenous variables $\left(\mathrm{Y}_{1}\right)$

$\alpha_{2}$ : Effect of exogenous variables $\left(\mathrm{X}_{2}\right)$ on endogenous variables $\left(\mathrm{Y}_{1}\right)$

$\beta_{1}$ : Effect of exogenous variables $\left(\mathrm{X}_{1}\right)$ on endogenous variables $\left(\mathrm{Y}_{2}\right)$

$\beta_{2}$ : Effect of exogenous variables $\left(\mathrm{X}_{2}\right)$ on endogenous variables $\left(\mathrm{Y}_{2}\right)$

$\beta_{3}:$ Effect of exogenous variables $\left(\mathrm{Y}_{1}\right)$ on endogenous variables $\left(\mathrm{Y}_{2}\right)$

\section{RESEARCH RESULT}

\section{Model Testing}

In order to choose the testing model there are three methods, namely Chow Test, Hausman Test and Langrenfe Multiplier Test (LM). The LM test needs to be done if the Chow Test results show the Common Effect and Fixed Effect and the Hausman Test shows the Random Effect as the appropriate model.

Table 2. Model Testing

\begin{tabular}{|c|c|c|}
\hline Model Testing & Chow Test & Hausman Test \\
\hline Equation 1 & 0.0000 & 0.1702 \\
\hline Equation 2 & 0.0000 & 0.0002 \\
\hline
\end{tabular}

Source: data processing (Eviews 10)

According to table 2 shows that the compatible test for equation model 1, the Random Effect (RE) model is better than the models of Fixed Effect (FE) and Common Effect (CE), without further testing (LM test) due to the value of the Prob Cross Section Random is 0.1702. this value is greater than the alpha value of 0.05. While for the equation model 2, the Fixed Effect (FE) model is better than the models of Random Effect (RE) and Common Effect (CE), without having to do the LM test.

\section{Coefficient of Determination}

Based on appendix 1 and 2 measurements of endogenous variables of the company's growth gained R2 value of 0.8249 or $82.49 \%$ and company's value of 0.8255 or $82.55 \%$. This indicates that the financial performance variables and capital structure are able to explain the company's growth variables and company's values of $82.49 \%$ and $82.55 \%$ while the remaining $17.51 \%$ and $17.45 \%$ are explained by other variables which are not contained in this research model.

\section{Simultaneous Test (Test of F Statistics)}

Furthermore, appendix 1 and 2 show the F statistical test which shows all independent variables have a simultaneous influence on the dependent variable. Results of $\mathrm{F}$ statistical test equation 1 prob value. $\mathrm{F}$ (statistic) is 0.000000 . where the value is smaller than the significance level of 0.05 (appendix 1), so it can be concluded that a decent regression model is used to explain 
the effect of financial performance (X1) and capital structure (X2) on the growth of the company (Y1). While the F statistical test equation 2 prob value. $\mathrm{F}$ (statistic) is 0.000000 . where the value is smaller than the significance level of 0.05 (appendix 2 ), thus it can be concluded that the regression model that is feasible is used to explain the effect of financial performance (X1) capital structure (X2), and growth of profit (Y1) on company's value (Y2).

\section{Partial Test (Test of $\mathbf{t}$ Statistic)}

Thus, the results of panel data regression analysis, as follows:

Table 3. Panel Data Regression Analysis Results

\begin{tabular}{|c|c|c|c|c|c|}
\hline $\begin{array}{c}\text { Variable Direct } \\
\text { Relations }\end{array}$ & $\begin{array}{c}\text { Regression } \\
\text { Coefficient }\end{array}$ & $\begin{array}{c}\text { Standard } \\
\text { Error }\end{array}$ & t-Statistic & Prob & Explanation \\
\hline $\mathbf{X 1} \rightarrow$ Y1 & 177.4533 & 75.01167 & 2.365676 & 0.0228 & Significant \\
\hline $\mathbf{X 2} \rightarrow$ Y1 & 91.62516 & 37.50861 & 2.442777 & 0.0190 & Significant \\
\hline $\mathbf{X 1} \rightarrow$ Y2 & 3.300839 & 1.101764 & 2.995957 & 0.0052 & Significant \\
\hline $\mathbf{X 2} \rightarrow \mathbf{Y 2}$ & 2.180480 & 1.020960 & 2.135715 & 0.0405 & Significant \\
\hline $\mathbf{Y 1} \rightarrow \mathbf{Y 2}$ & -0.005957 & 0.002751 & -2.165596 & 0.0379 & Significant \\
\hline
\end{tabular}

Source: Output Eviews 10

Based on the analysis results of the function equation Y1 and the function equation Y2, the results of the analysis of the research model can be seen as shown in Figure 2 as follows:

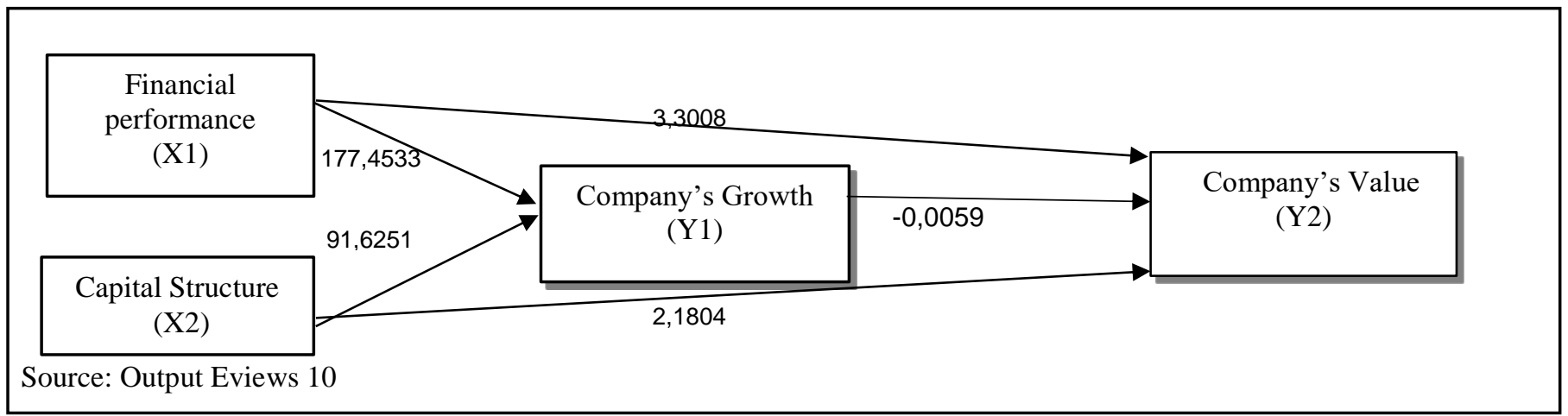

Figure 2. Results of Research Model Analysis

\section{DISCUSSION}

According to the results of processed data with output Eviews 10, relationships between variables are described as follows:

The influence of financial performance $(\mathrm{X} 1)$ is positive and significant to the growth of the company (Y1). The significance value possessed is 0.0228 , where the value is smaller than 0.05 , thus the independent variable X2 has a significant effect on the dependent variable Y1. While the regression coefficient for the financial performance variable is 177,453 . It means that, if there is an increase in financial performance, then the company's growth will increase by 177,453. The path coefficient shows a positive relationship, which means that the higher or better the financial performance of the company, then the higher or better the growth of Advertising, Printing and Media companies. The results of this study support the research conducted by Supriyanto (2014) showing that financial performance (ROA) has a positive and significant effect on company's growth. This result is in line with signaling theory which states that investors will invest in companies that give positive signals from companies which have high or good financial performance (ROA) and this is considered a good growth prospect in the future and investors also capture the signals that the company gives as important information. 
The influence of the capital structure (X2) is positive and significant to the growth of the company (Y1). The significance value owned is 0.0190 , where the value is smaller than 0.05 , thus the independent variable X2 has a significant effect on the dependent variable Y1. While the regression coefficient for capital structure variables is 91,625. That means, if there is an increase in the capital structure, then the growth of the company will increase by 91,625. The path coefficient shows a positive relationship, which means that the higher or better the capital structure of the company, then the higher or better the growth of Advertising, Printing and Media companies. The results of this study support the research conducted by Andriyani (2015) showing that the capital structure (DAR) has a positive and significant effect on company's growth (EG). The results of this study are in line with the pecking order theory which suggests that financial managers are advised to use the company's internal funds in the beginning and after that if internal funds are unable to finance operations, then managers are allowed to choose debt to support financing in financing company activities.

The influence of financial performance (X1) is positive and significant towards company's value (Y2). The significance value owned is 0.0052 , where the value is smaller than 0.05 , so the independent variable X1 has a significant effect on the dependent variable Y2. While the regression coefficient for financial performance variables is 3.300. This means that if there is an increase in financial performance, then the growth of the company will increase by 3.300 . The path coefficient shows a positive relationship, which means that the higher or better the financial performance of the company, then the higher or better the value of Advertising, Printing and Media companies. The results of this study support the research conducted by Chandra and Djajadikerta (2017) showing that financial performance (ROA) has a positive and significant effect on company's value. This result in accordance with the Signaling theory explains that investors will increase the demand for shares if the company's profitability increases, and on the other hand also increases the value of the company, because investors catch it as good information (positive) for the company because of the increase in profits of the company encouraging investors' expectations of returns to be high.

The effect of capital structure (X2) is positive and significant towards company's value (Y2). The significance value that is owned is 0.0405 , where the value is smaller than 0.05 , thus the independent variable $\mathrm{X} 2$ has a significant effect on the dependent variable Y2. While the regression coefficient for the capital structure variable is 2,180. It means, if there is an increase in the capital structure, then the value of the company will increase by 2,180. The path coefficient shows a positive relationship, which means that the higher or better the capital structure of the company, then the higher or better the value of Advertising, Printing and Media companies. The results of this study support the research conducted by Putri (2015) showing that the capital structure (DAR) has a positive and significant effect on company's value. This is in accordance with the traditional approach that there will be an optimal capital structure. This means that, the capital structure has an influence on the value of the company. Capital structure can be optimized by choosing good funding for the company to be able to obtain company's value.

The effect of company's growth (Y1) is negative and significant towards company's value (Y2). The significance value possessed is 0.0379 , where the value is smaller than 0.05 , so the independent variable Y1 has a significant effect on the dependent variable Y2. Whereas the regression coefficient for the company growth variable is 0.0059 . It means that the path coefficient shows a negative relationship, which means that the higher or better the growth of the company carried out by the company, then the lower value of the Advertising, Printing and Media companies. The results of this study support the research conducted by Suryani (2015) showing that the growth of the company has a negative and significant effect on company's value. This result in accordance with the Signaling theory explains that if the company has good prospects and growth in the future, investors will be optimistic about the prospect of the company, thus they will be interested in investing shares which will affect the company's share price, therefore financial managers need to review the opportunity prospects and growth to be more productive and in order to increase the value of the company for investors to be able to maximize the value of the company as a company's goal. 


\section{CONCLUSION AND SUGGESTION}

Based on the research carried out, thus it can be concluded that, First, financial performance (X1) has a positive and significant effect on company's growth (Y1). Second, capital structure (X2) has a positive and significant effect on company's growth (Y1). Third, financial performance (X1) has a positive and significant effect on company's value (Y2). Fourth, capital structure (X2) has a positive and significant effect on company's value (Y2). Fifth, company's growth (Y1) has a negative and significant effect on company's value (Y2).

Advertising, printing and Indonesian media companies must pay more attention to the usage of company's assets in order to be able to optimally provide increased growth rates from the operational activities carried out and to be able to provide prosperity to the company's shareholders. Companies in increasing company's growth and company's value must be able to balance the usage of funds between debt and assets. Advertising, printing and media companies must be more efficient in managing their assets in supporting and generating profits which will have an impact on increasing growth which will be responded positively by investors because it has provided a positive signal, so that the company's share price will increase which in the end can increase the company's value.

This research is expected to be able to help the company in making corporate financial decisions, because one decision will influence other financial decisions. Moreover, the company in increasing profit's growth and company's value must be able to balance the usage of funds. The usage of assets greater than debt will affect the financial performance and value of the company. Therefore, it is necessary to see the level of growth of a company, thus it will give a description that is suitable to be used in financing corporate obligations and further research is expected to add another manifest variable and expand the research sample not only focusing on some Advertising, Printing and Media companies.

\section{REFERENCES}

Badan Pusat Statistik/(BPS). (2017). Produk Domestik Bruto. (Online). (https://www.bps.go.id/produk-domestikbruto.html, di akses 24 September 2018).

Chandra, Haryani Dan Djajadikerta, Hamfri. (2017). Pengaruh Intellectual Capital, Profitabilitas, dan Leverage Terhadap Nilai Perusahaan Pada Perusahaan Sektor Properti, Real Estate, dan Konstruksi Bangunan yang Terdaftar di Bursa Efek Indonesia. Universitas Katolik Parahyangan. Ultima Accounting. Vol 9. No 2.

Chen, Ming Chin., Shu Ju Cheng, Yunchan Hwang. (2005). An Empirical Investigation Of The Relationship Between Intellectual Capital And Firms' Market Value And Financial Performance. Journal Of Intellectual Capital. Vol. 6 No. 2.

Colombage, Sisira R.N., (2007), Consistency and Controversy in Corporate Financing Practices: Evidence From An Emerging Market, Studies In Economics and Finance, Vol. 24:51-71.

Coluzzi, C., Ferrando, A., dan Carrascal, C. M. (2009). Financing Obstacles and Growth: An Analysis for Euro Area NonFinancial Corporation. Working Paper Series.

Fabozzi, Frank J. and Peterson, Pamela P., (2000), Financial Management and Analysis, Second Edition, John Wiley and Sons, Inc., Prentice Hall, New Jersey.

Gujarati, N Damodar dan Porter, C Dawn. (2013). Dasar-dasar Ekonometrika. Jakarta: Salemba Empat.

Hasnawati, Sri. (2005). Dampak Set Peluang Investasi terhadap Nilai Perusahaan Publik di Bursa Efek Jakarta. JAAAI Vol 9 No. 2 .

Husnan, Suad. 2013. Manajemen Keuangan. Edisi Keempat. Yogyakarta: BPFE-Yogyakarta.

International Monetary Fund. (2017). (online),World Economic Outlook(https://www.imf.org/external/datamapper/datasets/WEO, diakses 24 september 2018).

Kasmir. (2013). Analisis Laporan Keuangan, Jakarta: Rajawali Pers.

Machfoedz, Mas'ud. 1996. Akuntansi Manajemen, Perencanaan dan Pembuatan Keputusan Jangka Pendek. Buku 1. Edisi 5. Yogyakata: BPFE.

Myers, S. C dan N.S Majluf. (1984). "Corporate Financing \& Invesment Decision When Firm Have Information That Investor Do Not Have", Journal of Financial Economics, Vol. 13:187-221.

Putri, Winni Novia. (2015). Pengaruh Debt to Equity Ratio (DER), Debt to Asset Ratio (DAR), Ukuran Perusahaan dan Cash Holding Terhadap Nilai Perusahaan Manufaktur yang Terdaftar Di Bursa Efek Indonesia. Skripsi: Medan. Universitas Negeri Medan.

Safitri, Norma dan Aniek Wahyuati. 2015.Pengaruh Struktur Modal dan Keputusan Investasi Terhadap Profitabilitas dan Nilai Perusahaan. Jurnal Ilmu dan Riset Manajemen. Vol 4, No 2.

Sawir, Agnes. 2005. Analisis Kinerja Keuangan dan Perencanaan Keuangan. Jakarta: PT Gramedia Pustaka Utama. 
Supriyanto. (2014). Analisis Pengaruh Kinerja Keuangan Terhadap Pertumbuhan Laba Perbankan Di Bursa Efek Indonesia. Jurnal Ilman, Vol. 1, No. 1.

Suryani, Vivi Milanti. (2015). Pengaruh Pertumbuhan Perusahaan dan Struktur Modal Terhadap Nilai Perusahaan. Skripsi: Medan. Universitas Negeri Semarang.

Suteja, J. (2013). Manajemen Keuangan Perusahaan, Edisi 1. Bandung: Medio:77-93. 